\title{
Effect of milk minerals on calf gains and sex differences in mineral composition of milk from Iberian red deer (Cervus elaphus hispanicus)
}

\author{
L Gallego ${ }^{1}$, J A Gómez ${ }^{1}$, T Landete-Castillejos ${ }^{1,2,3}$, A J Garcia ${ }^{1,2,3}$, J A Estevez ${ }^{1,2,3}$, F Ceacero ${ }^{1,2,3}$, \\ $\checkmark$ Piñeiro ${ }^{4}$, X Casabiell ${ }^{4}$ and L F de la Cruz ${ }^{4}$ \\ ${ }^{1}$ Departamento de Ciencia y Tecnología Agroforestal, ETSIA and ${ }^{2}$ Grupo de Recursos Cinegéticos, Instituto de \\ Desarrollo Regional (IDR), Universidad de Castilla-La Mancha, 02071 Albacete, Spain, ${ }^{3}$ Animal Science Tech. \\ Applied to Wildlife Management Res. Group, IREC Sec. Albacete, Campus UCLM, 02071 Albacete, Spain and \\ ${ }^{4}$ Departamento de Fisiología, Universidad de Santiago, 27071 Lugo, Spain
}

Correspondence should be addressed to T Landete-Castillejos at Grupo de Recursos Cinegéticos, Instituto de Desarrollo Regional (IDR), Universidad de Castilla-La Mancha; Email: tomas.landete@uclm.es

\begin{abstract}
Milk mineral content has received little attention in studies focusing on milk nutrient effects on offspring growth. This study examines calf growth in Iberian deer and compares the influence of milk minerals, other nutrients, and lactation variables relevant for growth to discern the relative weight of each factor. In addition, because Iberian deer hinds are the first mammal found to produce different milk for sons and daughters, the present study examines whether there are also sex differences in milk mineral composition. Concentrations and yields of $\mathrm{Ca}, \mathrm{P}, \mathrm{Mg}, \mathrm{Na}, \mathrm{K}, \mathrm{Fe}$, and $\mathrm{Zn}$ in milk of 46 red deer hinds were monitored through 18 weeks of lactation. Calf growth was influenced by $\mathrm{Ca}$ and $\mathrm{P}$ percent, and total Fe production. Milk for males had a lower content in $\mathrm{Ca}$ and $\mathrm{P}$, a greater content of $\mathrm{K}$, and $\mathrm{Mg}$, whereas no sex effects were found in $\mathrm{Na}$, Fe, or $\mathrm{Zn}$ percentages. Higher percentages in $\mathrm{Ca}$ and $\mathrm{P}$ for daughters might constitute a compensatory response, as daily production was not biased towards females in $\mathrm{Ca}$ or $\mathrm{P}$, whereas in the latter and all the other minerals daily production was greater for heavier calves, which are usually males. In conclusion, milk mineral content and production influence calf growth even after controlling for other important lactation variables and nutrients, and they show effects and interactions more complicated than expected.

Reproduction (2009) 138 859-865
\end{abstract}

\section{Introduction}

Minerals constitute milk components that have received, to a large extent, little attention in animal science despite their importance in growth, physiological homeostasis, immunological function, and bone stability (McDowell 2003, Cashman 2006). In our own and other mammal species, factors affecting major milk components (protein, fat, and lactose) also affect the mineral content of milk, such as stage of lactation, milk accumulation, feed, and genetic variance (Peaker 1977, Vegarud et al. 2000). In one of the most studied cases of lactation of a wild mammal, Iberian deer, birth delay showed to have detrimental effects both in major milk nutrients and milk minerals which affected growth (Landete-Castillejos et al. 2000a, 2001, Gallego et al. 2006). However, these studies did not examine all mineral and nonmineral nutrients at the same time to discern their relative importance along with other lactation variables in influencing calf growth. Because of the important effect of $\mathrm{Ca}, \mathrm{Mg}$, and $\mathrm{Na}$ in skeleton and general body growth (McDowell 2003, Cashman 2006), it is very likely that the reduction found in these minerals (Gallego et al. 2006) might have produced synergic detrimental effects with the protein reduction found in earlier studies (Landete-Castillejos et al. 2000a). The study of milk minerals in this species may be particularly interesting because males receive more milk with a greater protein percent (Landete-Castillejos et al. 2005). However, in contrast to this finding, minerals play such a variety in physiological roles and complex interactions that it is very difficult to predict which minerals may be affected by sex and in what direction.

The current study examined milk mineral composition of macrominerals $\mathrm{Ca}, \mathrm{P}, \mathrm{Mg}, \mathrm{Na}$, and $\mathrm{K}$, and the two most essential microminerals, Fe and $\mathrm{Zn}$ in deer milk. The aim was to examine calf gains during lactation to assess the relative importance of mineral content versus other major milk nutrients and lactation variables. In addition, a second aim was to assess whether mineral composition and production was different in milk for male calves 
versus that for female calves as was found for protein percentage in a previous study. Because potentially, increased calf demands by one sex may produce sex biases if production of that mineral reaches a ceiling but milk production continues to grow. We attempted to assess such effects by: i) showing sex biases in milk production, and ii) examining if there is negative correlation between total milk yield and content of each mineral.

\section{Results}

Milk mineral content and their total production significantly influenced calf growth. Even after considering effects of calf birth-weight, sex (which had no effect once all other variables were taken into account), milk production and that of milk protein, fat and lactose, and birth date, calf growth was affected by mean $\mathrm{Ca}$ and $\mathrm{P}$ content, the interaction between $\mathrm{Ca}$ and $\mathrm{P}$ content, and total production of Fe. All these factors involving mineral content or production explained $36 \%$ of the variability explained by the model $(8.3,10.7,8.2$, and $9.6 \%$ respectively). The model was the following one $\left(R^{2}=78.1 \%\right)$ : calf gain (in $\left.\mathrm{kg}\right)=590 \pm 200$ (intercept) $+2.3 \pm 0.6$ calf birth-weight $(P<0.001)+1.3 \pm 0.2$ total milk protein production $(P<0.001)-0.24 \pm 0.09 \mathrm{Ca} \%$ $(P=0.009)-0.4 \pm 0.1 \mathrm{P} \%(P=0.004)-73 \pm 27$ total milk Fe production $(P=0.009)+0.00015 \pm 0.00005$ $\mathrm{Ca} \times \mathrm{P} \%(P=0.004)$. Sex, birth date, total milk, milk fat and milk lactose production, mean percentage of $\mathrm{K}, \mathrm{Na}$, $\mathrm{Mg}, \mathrm{Zn}, \mathrm{Fe}$, and total milk production of $\mathrm{Ca}, \mathrm{P}, \mathrm{K}, \mathrm{Na}$,
$\mathrm{Mg}$, and $\mathrm{Zn}$ were not significant. Because the negative coefficient for $\mathrm{Ca}$ and $\mathrm{P}$ may be considered as a negative effect of deviation from a $\mathrm{Ca}$ to $\mathrm{P}$ relationship (shown here as interaction $(\mathrm{C} \times \mathrm{P})$, we tested the same model substituting $\mathrm{Ca}$ and $\mathrm{P}$ by the residuals from the regression of Ca over $\mathrm{P}$ (dependent variable) and vice-versa. The resulting model showed the same positive or negative coefficient for all factors (in the case of $\mathrm{Ca}$ and $\mathrm{P}$, the coefficient for the residual variables were $-1.4 \pm 0.5$ and $-0.78 \pm 0.27$ respectively).

The results of Student's $t$-test to assess sex differences in calf birth-weight, calf-gains, and total milk production (which, as mentioned, disappear in some years), showed a greater weight at birth for males $\left(8.8 \pm 0.2\right.$ vs $7.8 \pm 0.2 \mathrm{~kg}$ for female calves, $t_{1,44}=3.27$, $P=0.002$ ), but not for calf-gains or total milk production of their mothers (calf gains: $28.1 \pm 1.2 \mathrm{~kg}$ for males versus $26.9 \pm 1.5 \mathrm{~kg}$ for female calves; total milk production: $191 \pm 8 \mathrm{I}$ for mothers of sons versus $187 \pm 11$ I for mothers of daughters; $t_{1,44}=0.62$ and 0.08 respectively, all $P>0.1$ ).

Table 1 shows the general linear mixed models (GLMM) for mean milk content and daily milk production of each mineral. Sex effects were found in percent of $\mathrm{Ca}, \mathrm{P}$, and $\mathrm{Mg}$, whereas marginal effects were found for $\mathrm{K}$ percent and no effect was found for ash, $\mathrm{Na}$, and Fe content. Zn showed a significant effect of calf birth-weight, which is usually higher in males. A greater content for males was found in $\mathrm{K}$ and $\mathrm{Mg}$, while a greater percent of $\mathrm{Ca}$ and $\mathrm{P}$ was found for female calves. $\mathrm{Zn}$ showed a higher content for heavier calves.

Table 1 General linear mixed models (GLMM) showing effects of week, calving delay with respect to first calf born (in days), calf birth weight and sex of the calf on milk mineral percent (A) and on daily production of milk minerals (B) in Cervus elaphus hispanicus.

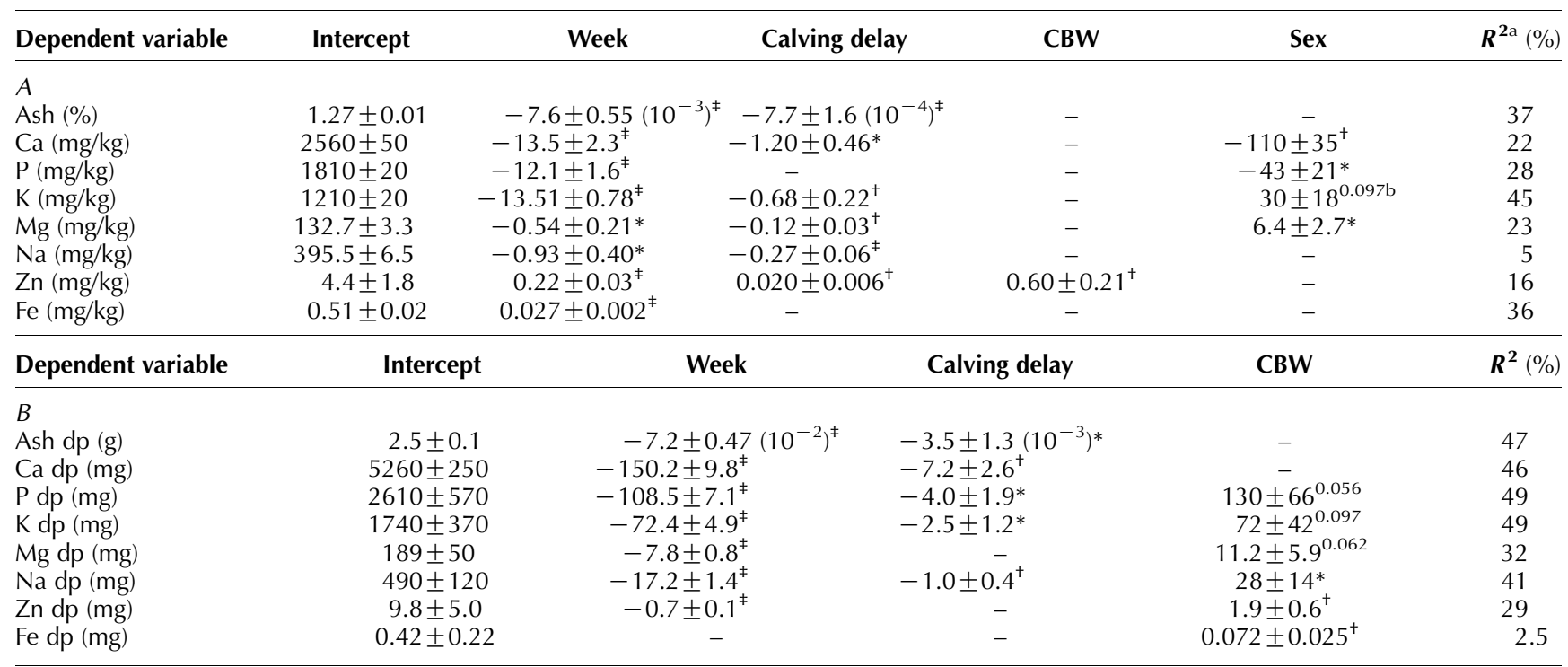

CBW, calf birth weight. Statistical significance at $P<0.05,0.01$ and 0.001 are indicated by ${ }^{*}{ }^{\dagger}$ and $^{\ddagger}$ respectively. Significance is based on $F$ ratios. ${ }^{a}$ Because general linear mixed models are based on restricted maximum likelihood and not least squares, it is not possible to calculate $R^{2}$ parameters to assess the variability explained. Thus, we have run the final model selected by stepwise backwards selection in a GLM to show this parameter as a rough, although imprecise, measure of the amount of variability explained by the model (which is higher than the value presented). ${ }^{b}$ Marginally significant values are indicated as the exact probability in superscript. 

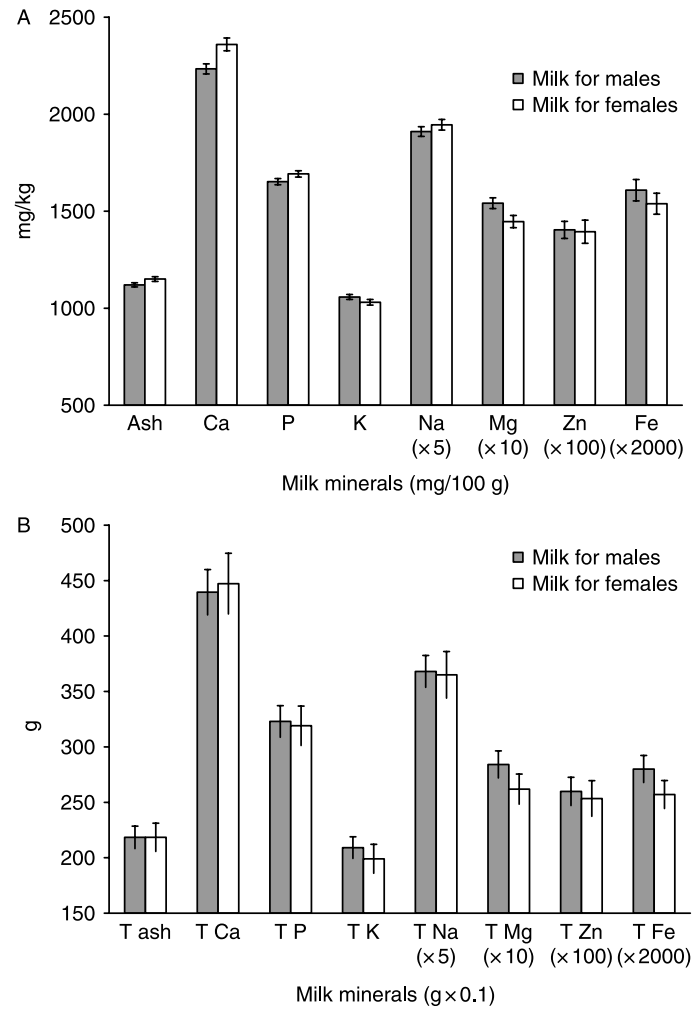

Figure 1 Differences in milk composition $(\mathrm{A}$, in $\mathrm{mg} / \mathrm{kg}$ ) and production ( $B$, in $g$ for the whole lactation period) for 24 male and 22 female calves of Iberian red deer, Cervus elaphus hispanicus. The bars indicate mean \pm S.E.M. Total production in grams for each element is indicated by the acronym $\mathrm{T}$ followed by the mineral component. Note that the values of mean and total composition of ash, $\mathrm{Na}, \mathrm{Mg}$, $\mathrm{Zn}$, and Fe have been multiplied by appropriate factors so that all are shown on a similar scale so that sex effects can be assessed.

Daily mineral production showed no sex effect, despite their effects in content in the case of Ca. In the case of K, $\mathrm{Mg}$, and $\mathrm{P}$, sex effects found in content disappeared and were absorbed by effects of calf birth-weight. It is particularly interesting in the case of $P$ because the GLMM model including sex but not calf birth-weight was influenced by calf sex (model $R^{2}$ corresponding to the same model but calculated by least squares $=$ $77.1 \%$; daily $\mathrm{P}$ (in $\mathrm{mg})=590 \pm 190$ (intercept) $-30 \pm 9$ week $(P<0.001)-2.1 \pm 0.7$ birth delay in days $(P=0.004)+1.81 \pm 0.04$ daily milk production in $\mathrm{ml}$
$(P<0.001)-120 \pm 60$ coefficient for males $(P=0.048))$. $\mathrm{Na}$ and Fe did not show sex effects in percentage nor daily production, but daily $\mathrm{Na}$ and Fe production was greater for heavier calves. Daily milk $\mathrm{Zn}$ production showed similar calf birth-weight effects to milk Zn percent (Fig. 1 and Table 1).

The correlations between mean milk mineral content and total milk production (Table 2) show an inverse relationship with $\mathrm{Mg}$ and $\mathrm{Fe}$, and a positive correlation with $\mathrm{K}$, but no effect on $\mathrm{Ca}, \mathrm{P}, \mathrm{Na}$, or $\mathrm{Zn}$. Figure 2 shows that both $\mathrm{Mg}$ and Fe reached a ceiling in total yield which deviated them from slope 1 with total milk production, an effect that is not found in the other minerals.

\section{Discussion}

The results found in this study showed that milk mineral content and production, affected calf-gains even after all other relevant lactation factors had been included in the model. An important finding was that milk mineral composition was different in milk for deer sons compared to that for daughters. The reason for this sex effect does not seem to be simple as it depends on each mineral.

The general linear model (GLM) for calf growth including mineral content and production in addition to all other relevant lactation variables showed that significant variables involving milk minerals explained more than a third of the total variability explained by the model for calf growth. This is rather astonishing considering that most of the variance was absorbed by calf birth-weight, which is strongly associated to calf growth (Landete-Castillejos et al. 2001, 2005) and total protein production, which strongly promotes growth (Landete-Castillejos et al. 2005). Out of the mineral effects on calf growth, perhaps the easiest to explain was the positive effect of the interaction $\mathrm{Ca}$ and $\mathrm{P}$. Both together form calcium phosphate, the main component of bone, and it is not surprising that their joint intake is needed for skeleton and general growth (McDowell 2003, Cashman 2006). In one of the best cases studied, humans, milk-extracted $\mathrm{Ca}$ phosphate and not other Ca sources was found to modify the trajectory of bone mass growth and caused a long-standing increase in bone mass accrual, which lasted beyond the end of

Table 2 Correlation between total milk yield (TMY) and mean mineral content of $\mathrm{Ca}, \mathrm{P}, \mathrm{Mg}, \mathrm{K}, \mathrm{Na}, \mathrm{Zn}$, and Fe in milk of $46 \mathrm{lberian}$ red deer hinds (Cervus elaphus hispanicus) and their calves.

\begin{tabular}{lcccccccc}
\hline & TMY & Ash & Ca & P & K & Na & Mg & Zn \\
\hline Ash & $0.26^{*}$ & & $0.89^{\S}$ & & & & & \\
$\mathrm{Ca}$ & - & $0.74^{\S}$ & $0.72^{\S}$ & & & & \\
$\mathrm{P}$ & - & $-38^{+}$ & $0.35^{\dagger}$ & - & - & & & \\
$\mathrm{K}$ & - & - & - & - & $-0.40^{\ddagger}$ & & \\
$\mathrm{Na}$ & - & $-0.36^{+}$ & - & - & $-0.29^{*}$ & - & - \\
$\mathrm{Mg}$ & $-0.48^{+}$ & $-0.29^{*}$ & - & - & - & - & $0.69^{\S}$ \\
$\mathrm{Zn}$ & $\mathrm{Fe}$ & & & - & & & \\
\hline
\end{tabular}

Significance level at $P<0.1,0.05,0.01$, and 0.001 is indicated respectively by $*,+,{ }^{*}$, and ${ }^{\S}$. 


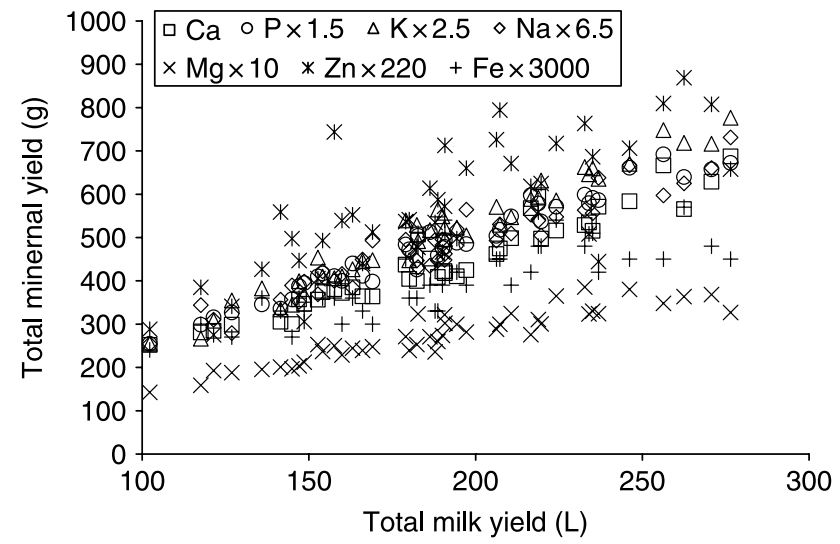

Figure 2 Total production of milk minerals (in g) versus total milk production (in I) for 46 hinds of Iberian red deer, Cervus elaphus hispanicus. Note that the values of $\mathrm{P}, \mathrm{K}, \mathrm{Na}, \mathrm{Mg}, \mathrm{Zn}$, and Fe have been multiplied by appropriate factors to show them i) on a similar scale, and ii) show more clear deviations from slope 1 at higher milk yields in $\mathrm{Mg}$ and Fe.

supplementation (Prentice 1997, Bonjour et al. 2001). On the contrary, it is rather more surprising than once this has been taken into the model, the effect of $\mathrm{Ca}$ or $\mathrm{P}$ alone negatively affected calf growth. Very few studies have shown evidence of any negative effects of nutrients that are ordinarily essential for growth. However, recent revisions including clinical studies have shown that despite its nutritive importance, excessive amounts of $P$ may be detrimental to bone, particularly when accompanied by low Ca consumption (Cashman 2006). A result corroborating the potential negative effect of deviations from $\mathrm{Ca}$ and $\mathrm{P}$ interaction, is that substituting $\mathrm{Ca}$ and $\mathrm{P}$ content by the residuals of the regression of $\mathrm{Ca}$ over $\mathrm{P}$ and vice-versa, these results showed a similar negative effect on calf growth in a GLM that also showed the same negative or positive effects for the rest of the factors kept in the model.

In addition to these effects, total Fe production was associated to low calf growth. At first instance, this might seem to be a detrimental effect of Fe in calf growth. However, a previous study (Gallego et al. 2006) showed that a rise in Fe content was associated with both reduction in milk production at the end of lactation and reduction in total milk production in late calving hinds. The authors concluded that this was in fact a compensatory response to maintain $\mathrm{Fe}$ and $\mathrm{Zn}$ supplies rather constant in situations were a constant flow of other milk nutrients could not be sustained (such as the more abundant $\mathrm{Ca}, \mathrm{P}, \mathrm{Na}$, or $\mathrm{Mg}$ ). Thus, the apparently negative effect of total milk Fe production on calf growth might, in fact, be a compensatory increase in Fe production for low growth calves that are receiving a low supply of all other milk nutrients and minerals. It is then surprising that no such effect was found for $\mathrm{Zn}$, which was also closely related to Fe in the study mentioned. One possibility is that when two factors are statistically highly correlated, if one is included in a model, the other one becomes non-significant. An analysis not included in the results showed that if total amount of Fe is substituted by total amount of $\mathrm{Zn}$, this shows a negative but non-significant effect on calf growth.

As interesting as the effects seen in calf growth was that sex did not exert a significant effect in the model or in the Student's $t$-tests. Both evidence, on free-ranging deer (Clutton-Brock et al. 1982) as well as our own results in previous studies, under ad libitum conditions without access to fresh pasture (Landete-Castillejos et al. 2001), shows a growth rate for male calves greater than that for females. This suggests that lactation effects such as sex biases reported here may also be modified by the availability of resources (a highly changing variable in free-ranging conditions) or even by the type of diet under ad libitum access to food.

Results showed that mineral composition was different in milk for male compared with the milk for female calves. This is a very interesting result, as to the best of our knowledge this is the first time that such a discovery has been made in any mammal. A previous study also showed for the first time that protein percent was greater in deer milk for male compared to that for female calves (Landete-Castillejos et al. 2005). The authors concluded that such an effect was a maternal investment to boost growth in males, which by becoming harem holders might benefit much more than females from reaching a large adult size. The effect was concluded to be driven by the mother rather than the calf, because sex was included in the models together with birth weight, so that the difference in milk composition for males compared with females could not be a non-adaptive response to greater nutrient demand by heavier calves. The sex effects might still constitute a non-adaptive response to a greater demand of nutrients by males irrespective of weight differences with females. The studies conducted so far in mammals (Guinea pigs: Cavia porcellus) on this respect show that an experimentally-induced increase in offspring nutrient demands does not induce greater milk production nor a change in milk composition by the mothers (Laurien-Kehnen \& Trillmich 2003). Increased demand, exerted via additional milkings in cattle does increase milk production (BarPeled et al. 1995, Wall \& McFadden 2008). Could an increase in demand produce a sex bias once a threshold has been reached for some minerals? In order to reach this effect, a sex bias in total milk production should be shown. This was found in an earlier study involving 96 lactations over a number of years (Landete-Castillejos et al. 2005) but not in the present study. The second condition for this effect to produce a bias is that such a ceiling in the production of some minerals is reached despite milk production (i.e. a dilution of that mineral at higher milk yields). This would produce a negative correlation between total milk production and percentage of milk minerals. This, in 
fact, is the case for $\mathrm{Mg}$ and Fe, but the first shows an increase of $\mathrm{Mg}$ for males, not a dilution, and the second shows no sex bias. We found no such threshold for $\mathrm{Ca}$ and $\mathrm{P}$, and thus, lower percentages of these minerals for males do not seem to be due to a dilution of their percentages in response to a greater milk production for males. Consistent with the previous finding, total mineral production of $\mathrm{Mg}$ and Fe versus total milk production (Fig. 2) show a linear increase at lower milk production, but seem to reach a ceiling at higher yield levels. In addition, a change in milk mineral composition produced by a greater milk dilution, as a result of increased production driven by demand of males, cannot be invoked to explain all sex effects in milk mineral composition because sex effects involve different responses for the same sex (increased percent of $\mathrm{Ca}$ and $\mathrm{P}$ for females, lower content of $\mathrm{K}$ and $\mathrm{Mg}$, and no difference for the other minerals). It seems, thus, more likely, that it may be a complicated maternal response rather than a simple non-functional response induced by a greater demand of male calves. Further experiments to clarify this point will be needed, and the most promising ones are cross-fostering experiments at some stage of lactation to see whether increased demand by males (or heavy and light weight males) induce a change in the trend of composition and daily production of each mineral.

However, interpreting sex effects in milk mineral composition does not seem as straightforward as the protein differences found in our earlier study. It seems a compensatory response in the case of the two most common minerals: $\mathrm{Ca}$ and P. Both showed a greater concentration in milk for females than in milk for males. However, daily milk Ca and P production was similar for males and females. Only in the case of $P$ was there a greater daily milk $\mathrm{P}$ production for heavier calves regardless of sex. Previous studies using large samples sizes and several years (Landete-Castillejos et al. 2005) showed that hinds produce more milk for male than for female calves. Thus, the greater $\mathrm{Ca}$ and $\mathrm{P}$ content in milk for female calves might compensate for the reduction in milk production.

$\mathrm{K}$ and $\mathrm{Mg}$ showed the opposite sex effects in content: greater content for males than for females. However, daily milk production was greater not in males, but in general in heavier calves. This is clearly not a compensatory response, as males grow faster than females. In addition to other roles, Mg plays an important role in bone formation because it can substitute $\mathrm{Ca}$ in bone hydroxyapatite, and in fact, $3 \%$ of bone is formed by $\mathrm{Mg}_{3}\left(\mathrm{PO}_{4}\right)_{2}$ (Doyle 1979, Ergun et al. 2002). The reason for a higher $\mathrm{Mg}$ content in milk for males might be linked to the role Mg plays in the skeleton because $70 \%$ of the body reserves of $\mathrm{Mg}$ are in the skeleton (Doyle 1979). In fact, the substitution of Ca by Mg makes the hydroxyapatite more compact and thus can have mechanical consequences for the skeleton (Ergun et al. 2002). Similarly, K seems to play an important role in bone formation which has not been recognized until very recently. Potassium explains $40 \%$ of the variability in antler weight in first year antler (Landete-Castillejos et al. 2007a). Both this, its variation in content within antler region, and the comparison of antler $\mathrm{K}$ content between deer populations (Landete-Castillejos et al. 2007b) support the role found in clinical studies where a greater $\mathrm{K}$ intake helps to reduce $\mathrm{Ca}$ losses in urine (Rafferty et al. 2005, Cashman 2006). In this case, a greater $\mathrm{K}$ percent in urine might reduce Ca losses in urine and thus promote its accretion in the skeleton. Thus, both sex differences in $\mathrm{Mg}$ and $\mathrm{K}$ content and their daily milk production might result from a greater need of bone growth efficiency in males. Such role in efficiency and trends in bone antler content are also found in $\mathrm{Zn}$ (Landete-Castillejos et al. 2007 b), which is associated to an important enzyme for bone creation: alkaline phosphatase (Maki et al. 2002, Robey \& Boskey 2003, Cashman 2006). However, in this case, it is striking that no sex effects were found in content and daily $\mathrm{Zn}$ production in deer milk. In this case, however, $Z n$ effects only followed the pattern found in daily $\mathrm{Mg}$ and $\mathrm{K}$ production of greater amounts for heavier calves. $\mathrm{Na}$ and Fe did not show any difference in their content in milk for male or female calves, and only their daily production in milk was greater for heavier calves, probably as a result of a greater milk production for these calves.

In conclusion, mineral content in deer milk is important for growth even after allowing for all other variables to explain their share of variability. In addition, milk mineral profile is different for male and female calves in Iberian deer. This appears to be a compensatory response to maintain constant $\mathrm{Ca}$ and $\mathrm{P}$ flow, although in other minerals it might be a maternal effect to promote efficiency in bone creation for male calves.

\section{Materials and Methods}

\section{Animals and sampling regimen}

Subjects included 46 Iberian red deer hinds and their calves (24 males, 22 females) kept in two groups (group A consisting of 11 male and 11 female calves, group B consisting of 13 male and 11 female calves and their mothers) each one in a $10000 \mathrm{~m}^{2}$ open door enclosure on an irrigated pasture including tall fescue, Festuca arundinacea (50\% at the start of the experiment), orchardgrass or cocksfoot, Dactylis glomerata $(30 \%)$, lucerne, Medicago sativa $(15 \%)$, and white clover, Trifolium repens (5\%). There is only $1 \%$ of twinning in deer (Sadleir 1987), so twins are always excluded from our studies. The hinds age ranged from 2 to 9 years. Because birth-date delay (with respect to first calf born) is an important variable affecting many lactation variables (Landete-Castillejos et al. $2000 b, 2001)$, we set-up the experiment to have an extended birth date to assess this effect. Thus, hinds calved from 16 May to 4 October all in the same reproductive season. Mean birth date was 25 July in group A and 29 July in group B (mean \pm s.E.M. birth delay with respect to first calf born $74 \pm 6$ days 
for the whole group; $72 \pm 8$ days for group $A$ and $76 \pm 8$ days for group B). Groups were balanced for calf sex (group A: 11 males, 12 females; group B: 13 males, 10 females), birth date, and hind weight after calving (calf birth weight: group $A, 8.2$ $\pm 0.25 \mathrm{~kg}$; group $B, 8.4 \pm 0.2 \mathrm{~kg}$; calf gains during lactation: group A, $26.4 \pm 1.4 \mathrm{~kg}$; group $B, 28.7 \pm 1.3 \mathrm{~kg}$; hind weight after calving: group A, $95.6 \pm 2.2 \mathrm{~kg}$; group B, $99.8 \pm 3.2 \mathrm{~kg}$ ). Calf-gains during lactation were considered as the difference between the weigh at weaning (week 18) and weight at birth. We performed Student's $t$-tests to check the lack of statistical differences between groups in calf birth-weight, calf-gains, and hind weight after calving $\left(t_{1,44}=-0.57 ; t_{1,44}=-1.17\right.$ and $t_{1,44}=-1.01$ respectively).

Both during gestation and throughout lactation, hinds were fed ad libitum with diets based on suggestions by Brelurut et al. (1990), using barley straw and meal from barley, alfalfa, oat, and sugar beets. Calves had access to feed from hinds, although during daily surveillance they were not observed to feed on them during the experiment. No record of individual intake of food was attempted. Table 3 shows nutrient composition of pasture and meal.

Milking was conducted on week 2, 4, 6, 10, 14, and 18 of lactation (the standard length of lactation, see review in Landete-Castillejos et al. (2000a, 2000b)). Hinds were isolated from calves for $6 \mathrm{~h}$ with no pre-isolation milking for ethical reasons explained in Landete-Castillejos et al. (2000a). Individuals were milked under anesthesia (xylazine at $0.5 \mathrm{mg} / \mathrm{kg}$ body mass; ketamine at $1 \mathrm{mg} / \mathrm{kg}$; reverted with yohimbine $0.25 \mathrm{mg} / \mathrm{kg}$ ) using a machine milking set-up to $50 / 50$ massage/milking ratio and $44 \mathrm{kPa}$ of vacuum. Once anesthesia was induced, $10 \mathrm{IU}$ of oxytocin were injected in the right jugular vein $1 \mathrm{~min}$ before milking to induce milk letdown. Milk production and composition were assessed as explained in Landete-Castillejos et al. (2000b, 2001). From the pool of milk obtained for each hind and milking, $50 \mathrm{ml}$ of milk samples were collected for use in analyses determining mineral content and that of other major nutrients. Protein, fat, and lactose concentrations were computed as the mean of the two replicates from each milking. Daily milk production was considered as four times the total milk collected after a 6-h isolation period between mother and calf (Landete-Castillejos et al. 2000a, 2000 b). Total production of milk was computed as the mean between the daily milk production at two

Table 3 Table showing main nutrients and minerals of pasture and meal offered to captive Cervus elaphus hispanicus stags, and water mineral composition (estimated similarly as explained in methods for milk analysis).

\begin{tabular}{lrrc}
\hline Nutrient & Pasture & Meal & Water $(\mathrm{mg} /)^{\mathrm{a}}$ \\
\hline Crude protein $(\%)$ & 19 & 16 & - \\
$\mathrm{Ca}(\mathrm{mg} / \mathrm{kg})$ & 14600 & 6400 & 45.4 \\
$\mathrm{~K}(\mathrm{mg} / \mathrm{kg})$ & 30100 & 7000 & 3.97 \\
$\mathrm{Mg}(\mathrm{mg} / \mathrm{kg})$ & 5200 & 2200 & 74.3 \\
$\mathrm{Si}(\mathrm{mg} / \mathrm{kg})$ & 15700 & 1900 & 4.53 \\
$\mathrm{Na}(\mathrm{mg} / \mathrm{kg})$ & 345 & 519 & 15.0 \\
Zn $(\mathrm{mg} / \mathrm{kg})$ & 49 & 26 & 0.29 \\
Fe $(\mathrm{mg} / \mathrm{kg})$ & 759 & 199 & 0.00
\end{tabular}

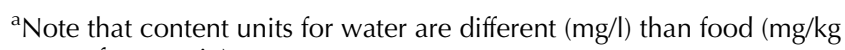
except for protein). consecutive milkings multiplied by the time period between them, and then adding up the results for all milking periods. For total protein, fat, lactose production and that of minerals, the milk production was multiplied by protein, fat, lactose content or that of each mineral and then a similar procedure was carried out as for calculating total milk production.

\section{Mineral analyses}

To prepare for mineral analyses, $10 \mathrm{ml}$ milk samples were dried for $3 \mathrm{~h}$ at $102{ }^{\circ} \mathrm{C}$, and then for $24 \mathrm{~h}$ at $130{ }^{\circ} \mathrm{C}$. After this period, the samples were incinerated at $520^{\circ} \mathrm{C}$ for $12 \mathrm{~h}$. The amount of ash was then weighed to be used in statistical analyses. The minerals in ashes were dissolved with $10 \mathrm{ml}$ of $3 \mathrm{M} \mathrm{HCl}$ and then heated until the dilution emitted white smoke. After cooling, the samples were filtered with paper ALBET REF.1300 (Filalbert, Barcelona, Spain) in a $50 \mathrm{ml}$ volumetric flask and the process was repeated in the capsule that contained the ashes to dissolve any remains. The volume was completed with ultrapure water so that a $1 / 5$ dilution resulted for analysis. The $1 / 5$ dilution was directly used for $\mathrm{Fe}$, but $\mathrm{Zn}$ was diluted to 1/10, $\mathrm{Na}$ and $\mathrm{Mg}$ were diluted to $1 / 250$, and $\mathrm{Ca}$ and $\mathrm{K}$ were diluted to $1 / 500$ to adjust concentrations to calibration lines.

Minerals in the ash samples were examined with an atomic absorption spectrophotometer (Perkin-Elmer 2280; PerkinElmer, Waltham, MA, USA). The concentration of $\mathrm{Ca}, \mathrm{Mg}, \mathrm{Fe}$, and $\mathrm{Zn}$ were analyzed with atomic absorption spectrophotometry, whereas $\mathrm{K}$ and $\mathrm{Na}$ were examined using atomic emission (using the same equipment without the hollow cathode lamp used above). In the case of $\mathrm{Ca}, 0.2 \%$ lanthanum trichloride was used to prevent interference from other elements. The spectrum lines for $\mathrm{Ca}, \mathrm{Mg}, \mathrm{Na}, \mathrm{K}, \mathrm{Zn}$, and $\mathrm{Fe}$ were 422.7, 285.2, 589.0, 766.5, 213.9, and 248.3 respectively. Absorbance was measured at 2-s intervals. Each datum was the mean of five measures recorded at the interval mentioned, after checking that their variation coefficient was smaller than $2 \%$. For $\mathrm{P}$ determination, u.v. visible spectrophotometry was used according to the colorimetric method, analyzing it as phosphomolybdic acid according to Osborne \& Voogt (1978). The equipment used was a Shimadzu u.v. 1230 spectrophotometer at $650 \mathrm{~nm}$ wave lengths (Shimadzu Co., Kyoto, Japan).

To assess the precision of the method used to determine mineral concentration, we analyzed five samples of skimmed milk powder supplied by the Community Bureau of Reference (BCR-63).

\section{Statistical analyses}

A GLM examined calf growth as a dependent variable to assess effects of the following factors: calf birth-weight, sex, calving delay with respect to the first calf born, and percent and total production of milk protein, fat, lactose, and the minerals mentioned above. Interactions were assessed as in linear regression, by examining the product of continuous variables or as dummy variables in the case of sex. Prior to assess sex differences in milk mineral concentration and production, a one-way ANOVA examined gross sex differences in calf birthweight, calf-gains, and total milk production, as some of the 
effects are not significant for small sample sizes or certain years by effects not entirely understood.

Sex differences in milk mineral composition were assessed using a repeated measures GLMM which examined the percentage and daily production of each mineral as dependent variables. Calf identity was entered as subject (blocks), whereas week (stage of lactation) was entered as repeated measure. The model examined the following factors: sex, stage of lactation, and its squared term to assess curvilinear responses, calf birthweight and birth-date delay (in days with respect to first calf born that year). A different model was carried out for each mineral (eight different models for production, and their corresponding models for daily production: ashes, Ca, P, K, $\mathrm{Na}, \mathrm{Mg}, \mathrm{Zn}$, and Fe). Because sex effects could arise as a by-product of a fixed demand per unit of weight of the calf as males are heavier than females, the analysis tested for pure sex effects irrespective of body weight by including calf birth weight as a factor. This cannot rule out a non-functional response by hinds producing a greater percentage of minerals induced by a sex-specific increased demand irrespective of calf birth-weight. Alternatively, sex biases may arise if there is greater milk production for one sex and mineral yield reached a threshold, thus, diluting it at larger milk yields. To test for this we examined: first, if there was a sex bias in milk production by a simple $t$-test; and second, if there is a threshold effect in mineral production by correlating mineral content with total milk production. In order to test if increased production may produce All statistical analyses were performed using SPSS (version 15.0, SPSS Inc., Chicago, IL, USA).

\section{Declaration of interest}

The authors declare that there is no conflict of interest that could be perceived as prejudicing the impartiality of the research reported.

\section{Funding}

This research has been partly funded by MCEI-FEDER project CGL2008-00749/BOS.

\section{Acknowledgements}

The authors wish to thank Fulgencio Cebrián and Isidoro Cambronero for help in handling the animals and two anonymous referees for their helpful comments. The authors wish to thank three anonymous referees for their helpful comments.

\section{References}

BarPeled U, Maltz E, Bruckental I, Folman Y, Kali Y, Gacitua H, Lehrer AR, Knight CH, Robinzon B, Voet H et al. 1995 Relationship between frequent milking or suckling in early lactation and milk production of high producing dairy cows. Journal of Dairy Science 78 2726-2736.

Bonjour JP, Chevalley T, Ammann P, Slosman D \& Rizzoli R 2001 Gain in bone mineral mass in prepubertal girls 3.5 years after discontinuation of calcium supplementation: a follow-up study. Lancet 358 1208-1212.
Brelurut A, Pingard A \& Thériez M 1990 Le Cerf et son Elevage, Paris: INRA.

Cashman KD 2006 Milk minerals (including trace elements) and bone health. International Dairy Journal 16 1389-1398.

Clutton-Brock TH, Guinness FE \& Albon SD 1982 Red Deer: Behavior and Ecology of Two Sexes, Edinburgh: Edinburgh Univ. Press.

Doyle JJ 1979 Toxic and essential elements in bone - a review. Journal of Animal Science 49 482-497.

Ergun C, Webster TJ, Bizios R \& Doremus RH 2002 Hydroxylapatite with substituted magnesium, zinc, cadmium, and yttrium. I. Structure and microstructure. Journal of Biomedical Materials Research 59 305-311.

Gallego L, Landete-Castillejos T, García AJ \& Sánchez PJ 2006 Seasonal and lactational changes in mineral composition of milk from lberian red deer (Cervus elaphus hispanicus). Journal of Dairy Science 89 589-595.

Landete-Castillejos T, García AJ, Molina P, Vergara H, Garde J \& Gallego L 2000a Milk production and composition in captive Iberian red deer (Cervus elaphus hispanicus): effect of birth date. Journal of Animal Science 78 2771-2777.

Landete-Castillejos T, García A, Garde J \& Gallego L 2000 b Milk intake and yield curves and allosuckling in captive lberian red deer (Cervus elaphus hispanicus). Animal Behaviour 60 679-687.

Landete-Castillejos T, García AJ \& Gallego L 2001 Calf growth in captive Iberian red deer (Cervus elaphus hispanicus): effect of birth date and hind milk production and composition. Journal of Animal Science $\mathbf{7 9}$ 1085-1092.

Landete-Castillejos T, García AJ, López-Serrano FR \& Gallego L 2005 Maternal quality and differences in milk production and composition for male and female Iberian red deer calves (Cervus elaphus hispanicus). Behavioral Ecology and Sociobiology 57 267-274.

Landete-Castillejos T, García AJ \& Gallego L 2007a Body weight, early growth and antler size influence antler bone mineral composition of Iberian red deer (Cervus elaphus hispanicus). Bone 40 230-235.

Landete-Castillejos T, Estevez JA, Martínez A, Ceacero F, García AJ \& Gallego L 2007b Does chemical composition of antler bone reflect the physiological effort made to grow it? Bone 40 1095-1102.

Laurien-Kehnen C \& Trillmich F 2003 Lactation performance of guinea pigs (Cavia porcellus) does not respond to experimental manipulation of pup demands. Behavioral Ecology and Sociobiology 53 145-152.

Maki K, Nishioka T, Nishida I, Ushijima S \& Kimura M 2002 Effect of zinc on rat mandibles during growth. American Journal of Orthodontics and Dentofacial Orthopedics 122 410-413.

McDowell LR 2003 Minerals in Animal and Human Nutrition, Amsterdam: Elsevier.

Osborne DR \& Voogt P 1978 The Analysis of Nutrients in Foods, London: Academic Press.

Peaker M 1977 The aqueous phase of milk: ion and water transport. Symposia of the Zoological Society of London 41 113-134.

Prentice A 1997 Is nutrition important in osteoporosis? Proceedings of the Nutrition Society 56 357-367.

Rafferty K, Davies KH \& Heaney RP 2005 Potassium intake and the calcium economy. Journal of the American College of Nutrition 24 99-106.

Robey PG \& Boskey AL 2003 Extracellular matrix and biomineralization of bone. In Primer on the Metabolic Bone Diseases and Disorders of Mineral Metabolism, pp 38-46. Ed. MJ Favus. Washington: American Society for Bone and Mineral Research.

Sadleir RMFS 1987 Reproduction of female cervids. In Biology and Management of the Cervidae, pp 123-177. Ed. CE Wemmer. Washington: Smithsonian Institution Press.

Vegarud GE, Langsrud T \& Svenning C 2000 Mineral-binding milk proteins and peptides; occurrence, biochemical and technological characteristics. British Journal of Nutrition 84 S91-S98.

Wall EH \& McFadden TB 2008 Use it or lose it: enhancing milk production efficiency by frequent milking of dairy cows. Journal of Animal Science 86 S27-S36.

Received 22 January 2009

First decision 10 March 2009

Revised manuscript received 22 July 2009

Accepted 5 August 2009 